\title{
Author Index to Volume 14 (1995)
}

Badham, R., Couchman, P. and Little, S., Getting Smart: Developing an Action Research Approach to the Integrated Management of Technical and Organizational Innovation, (1) 91-104

Baruch, Y., Business Globalization - The Human Resource Management Aspect, (4) 313-326

Benoit, C.A. and Mackenzie, K.D., The Science of an Organization. Part II: Realizing a New Model of Organizational Learning, (2) 119-132

Brooks, H., The Cost of Bribery and Self-Dealing in the S\&L Failures, (2) 179-187

Bush, D.H., see Dooley, K.J., (4) 291-306

Coman, A. and Ronen, B., The Enhanced Makeor-Buy Decision: The Fallacy of Traditional Cost Accounting and the Theory of Constraints, (4) 303-308

Couchman, P., see Badham, R., (1) 91-104

Doktor, R., Differences in the Conceptualization of Cause and Effect Relationships Found between Asian and Anglo Managers, (2) 113-118

Dooley, K.J., Johnson, T.L. and Bush, D.H., TQM, Chaos and Complexity, (4) 287-302

Georgantzas, N.C., Strategy Design TradeoffsFree, (2) 149-161

Hofstede, G., Multilevel Research of Human Systems: Flowers, Bouquets and Gardens, (3) 207217

Ibarra Colado, E., Strategic Analysis of Organizations: A Model from the Complexity Paradigm, (1) $51-70$

Irwin, H. and More, E., International Technology Transfer, Intercultural Communication and the Australian Aerospace and Telecommunications Industries, (1) 39-50

Johnson, T.L., see Dooley, K.J., (4) 291-306

Kagan, D., Why Entrepreneurs Ignore Good Advice: A Study in Non-Linearity and $\mathrm{Ego}^{\odot}$, (4) 327-333

Katz, J.E., Transforming Corporate Culture in the US Tele-communications Industry: Notes on So-

IOS Press

Human Systems Management 14 (1995) 347-348 cial Engineering, (1) 21-38

Kim, Y.-S., Technological Development and R\&D Policy: The Case of Korea, (3) 249-258

Kondo, Y., Are Creativity and Standardization Mutually Exclusive?, (4) 309-312

Lin, B., Vassar, J.A. and Martin, C.L., Strategic Implications of the Service Factory for Small Manufacturers, (3) 219-226

Little, S., see Badham, R., (1) 91-104

Mackenzie, K.D., see Benoit, C.A., (2) 119-132

Mackenzie, K.D., The Science of an Organization. Part III: Organizational Problem Solving During the ODS Process, (2) 133-148

Martin, C.L., see Lin, B., (3) 219-226

Maruyama, M., Misconceptions Regarding Communist Regime and Post-Communist Reform in Russia (Editorial Comment), (3) 263-265

Mathews, J., Organisational Innovation: Competing Models of Productive Efficiency, (1) 71-90

More, E., see Irwin, H., (1) 39-50

Nodoushani, O., The Professional Ideal in Management History, (4) 335-345

Romme, A.G.L., see Van Olffen, W., (3) 199-206

Ronen, B., see Coman, A., (4) 307-312

Singer, A.E., Guest-Editor's Preface: Organizational-Capital and Productivity, (1) 1-2

Singer, A.E., Competitiveness as Hyper-Strategy, (2) $163-178$

Tremblay, P., The Organisational Assets of the Learning Firm, (1) 7-20

Turban, E. and Wang P., Telecommuting Management: A Comprehensive Overview, (3) 227238

Van Olffen, W. and Romme, A.G.L., The Role of Hierarchy in Self-Organizing Systems, (3) 199206

Warner, M., Managing China's Human Resources, (3) 239-248

Van Gigch, J.P., Liberté, Egalité, Fraternité in the International World of Publishing: How to Get Recognition as an Author (Editorial Comment), (3) 259-262

Vassar, J.A., see Lin, B., (3) 219-226 
Wang P., see Turban, E., (3) 227-238

Zeleny, M., Editorial: Reengineering, (2) 105-108

Zeleny, M., Editorial: Global Management Paradigm, (3) 191-194
Zeleny, M., Editorial: Human and Social Capital Prerequisites for Sustained Prosperity, (4) 279282 